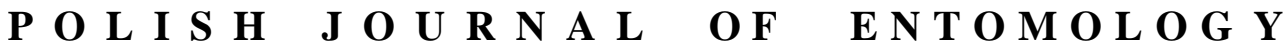

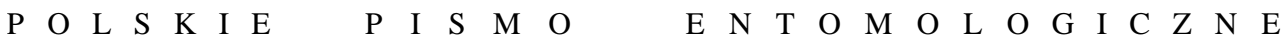

VOL. 84: $339-349$

Lublin

30 December 2015

DOI: $10.1515 /$ pjen-2015-0029

\section{A new species Flatopsis wojciechowskii from Nosy-Komba and Madagascar (Hemiptera: Fulgoromorpha: Flatidae)*}

\author{
DARIUSZ ŚWIERCZEWSKI ${ }^{1}$, ADAM STROIŃSKI $^{2}$ \\ ${ }^{1}$ Department of Zoology and Animal Ecology, Jan Długosz University, Al. Armii Krajowej \\ 13/15, 42-201 Częstochowa, Poland, e-mail: dswier@ajd.czest.pl \\ ${ }^{2}$ Museum and Institute of Zoology PAS, Wilcza 64, 00-679 Warszawa, Poland, \\ e-mail: adam@miiz.waw.pl
}

\begin{abstract}
A new planthopper species of the family Flatidae Flatopsis wojciechowskii sp. n. from the islands of Nosy-Komba and Madagascar is described and illustrated.
\end{abstract}

KEY WORDS: Fulgoromorpha, Flatidae, new species, biodiversity, Madagascar.

\section{INTRODUCTION}

Madagascar is one of eight important global biodiversity hotspots owing to its unique biotas and the high degree of threat to its natural habitats (MCNEELY et al. 1990, MYERS et al. 2000, GANZHORN et al. 2001). Once a part of the southern supercontinent Gondwana, it started to separate from Africa as a Madagascar-India continent ca 130 million years ago. Then, at ca 90 my, India began to break off from Madagascar and drift north-eastwards (ALI \& AITCHISON 2008). Madagascar has evolved an incredible wealth of biodiversity, with thousands of species that can be found nowhere else on Earth. For example, nearly 10000 of its estimated 12000 plant species are unique to Madagascar (GAUTIER \& GOODMAN 2007).

\footnotetext{
* The paper is dedicated to Prof. Wacław WOJCIECHOWSKI in recognition of his great contribution to the taxonomy and faunistics of Hemiptera.
} 
Flatidae constitutes one of the largest families within planthoppers (Fulgoromorpha, Hemiptera) with 1420 described species in 297 genera, covering 2 subfamilies: Flatinae SPINOLA, 1839, divided into 13 tribes, and Flatoidinae MELICHAR, 1901 (BouRgoIN 2015). Highly diverse in colour and size (from 4.5 to $32 \mathrm{~mm}$ ), these phytophagous insects are found on all continents but are especially common and abundant in the tropics (O'BRIEN 2002). About 20 species of Flatidae are regarded as serious pests of economically important crops (WILSON \& O'BRIEN 1986); the only pest in Europe Metcalfa pruinosa (SAY, 1830) was first introduced into Italy from the USA in 1983 (MIFSUD et al. 2010).

The genus Flatopsis was established by MeLICHAR (1902) for two species: Phyllyphanta nivea SIGNORET, 1860 and Flatopsis guttifera MELICHAR, 1902, which are readily distinguished by the characteristic colouration of the tegmina in the latter. Moreover, Flatopsis nivea exists in two colour variations, named Flatopsis nivea nigropunctata (STÅL, 1866) and Flatopsis nivea basipunctata (SCHMIDT, 1924). Recently, ŚWIERCZEWSKI \& STROIŃSKI (2011) described a new species - Flatopsis medleri ŚWIERCZEWSKI et STROIŃSKI, 2011 - from south-eastern Madagascar. Here, we describe a further species from Nosy-Komba and northern Madagascar.

\section{MATERIAL AND METHODS}

The specimens studied in the course of this work are deposited in the following collections: ISNB - Institut Royal des Sciences Naturelles de Belge, Bruxelles (Belgium); MNHN - Muséum national d'Histoire naturelle, Paris (France); NMPC - National Museum, Department of Entomology, Prague (Czech Republic).

The abdomens of the specimens examined were removed and cleared for $30 \mathrm{~min}$. in warm $\left(50^{\circ} \mathrm{C}\right) 10 \% \mathrm{KOH}$ with a few drops of chlorazol black to stain the genital structures based on the method introduced by CARAYON (1969) and BOURGOIN (1993). Dissections and cleaning of genital structures were performed in distilled water. Final observations and drawings were done in glycerine using a camera lucida attached to a light microscope. All colour images were taken using a stereomicroscope Leica MZ 16 equipped with an IC 3D digital camera. The final images were produced using Helicon Focus and Adobe Photoshop software. The SEM photographs of uncoated specimens were taken in the Laboratory of Scanning Microscopy, MIZ PAS (Warsaw), using a HITACHI S-3400N scanning electron microscope under low vacuum conditions.

The following measurements made with an ocular micrometer, ratios and abbreviations are used in this study: total length - measured (in dorsal view) from apex of head protrusion to apex of tegmina; $\mathrm{A} / \mathrm{B}$ - width of vertex measured at anterior margin/length of vertex measured at midline; C/E - width of frons between eyes/length of frons at midline; 
$\mathrm{D} / \mathrm{E}$ - maximum width of frons/length of frons at midline; $\mathrm{F} / \mathrm{B}$ - length of pronotum at midline/length of vertex at midline; G/F - length of mesonotum/length of pronotum at midline; $\mathrm{G} / \mathrm{B}+\mathrm{F}$ - length of mesonotum/cumulative length of vertex and pronotum at midline; $\mathrm{G} / \mathrm{H}$ - length of mesonotum at midline/width of mesonotum between lateral angles; I/J - length of tegmen measured from base to apical margin in median portion/width of tegmen measured from apex of clavus to anterior margin.

Vein nomenclature follows the interpretation proposed by BOURGOIN et al. (2015). Antennal structures are named in accordance with STROIŃSKI et al. (2011). The terminology of the male genitalia follows BOURGOIN (1988) and BOURGOIN \& HUANG (1990).

\section{RESULTS}

Family Flatidae SPINOLA, 1839

Subfamily Flatinae SPINOLA, 1839

Tribe Lawanini MELICHAR, 1923

Genus Flatopsis MELICHAR, 1902

\section{Taxonomic note}

MELICHAR's monograph is divided into two parts; in the first part the genus Flatopsis is only mentioned in the section key to genera as "gen. n." (MELICHAR 1901: 198), while the second part gives full descriptions of the genus and species (MELICHAR 1902: 51).

\section{Flatopsis wojciechowskii sp. n.}

(Figs 1-22)

\section{Diagnosis}

Flatopsis wojciechowskii sp. nov. differs from other species belonging to the genus in the following male characters: apical part of anal tube in lateral view elongated, ventral side with gibbosity; process of periandrium 2-armed with ventral arm diverged apically.

\section{Material examined}

Holotype, $\widehat{\partial}$ (label inscriptions under the specimen given verbatim in square brackets): [NOSY - KOMBA Sommet 5/56 A.R.], [Institut Scientifique Madagascar], [Flatopsis

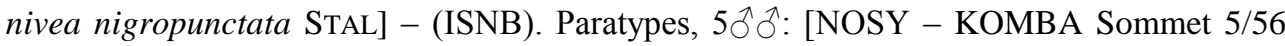
A.R.], [Flatopsis nivea (SIGNORET) det. MEDLER, 1987], [tip of ventral process atypical] $1 \delta$ (ISNB); [NOSY - KOMBA Sommet 5/56 A.R.], [Institut Scientifique Madagascar], [R. I.Sc.N.B.I.G. 22.889] - 1ð (ISNB); [Ampanefena Madagascar Mus. Praha], [Collectio 

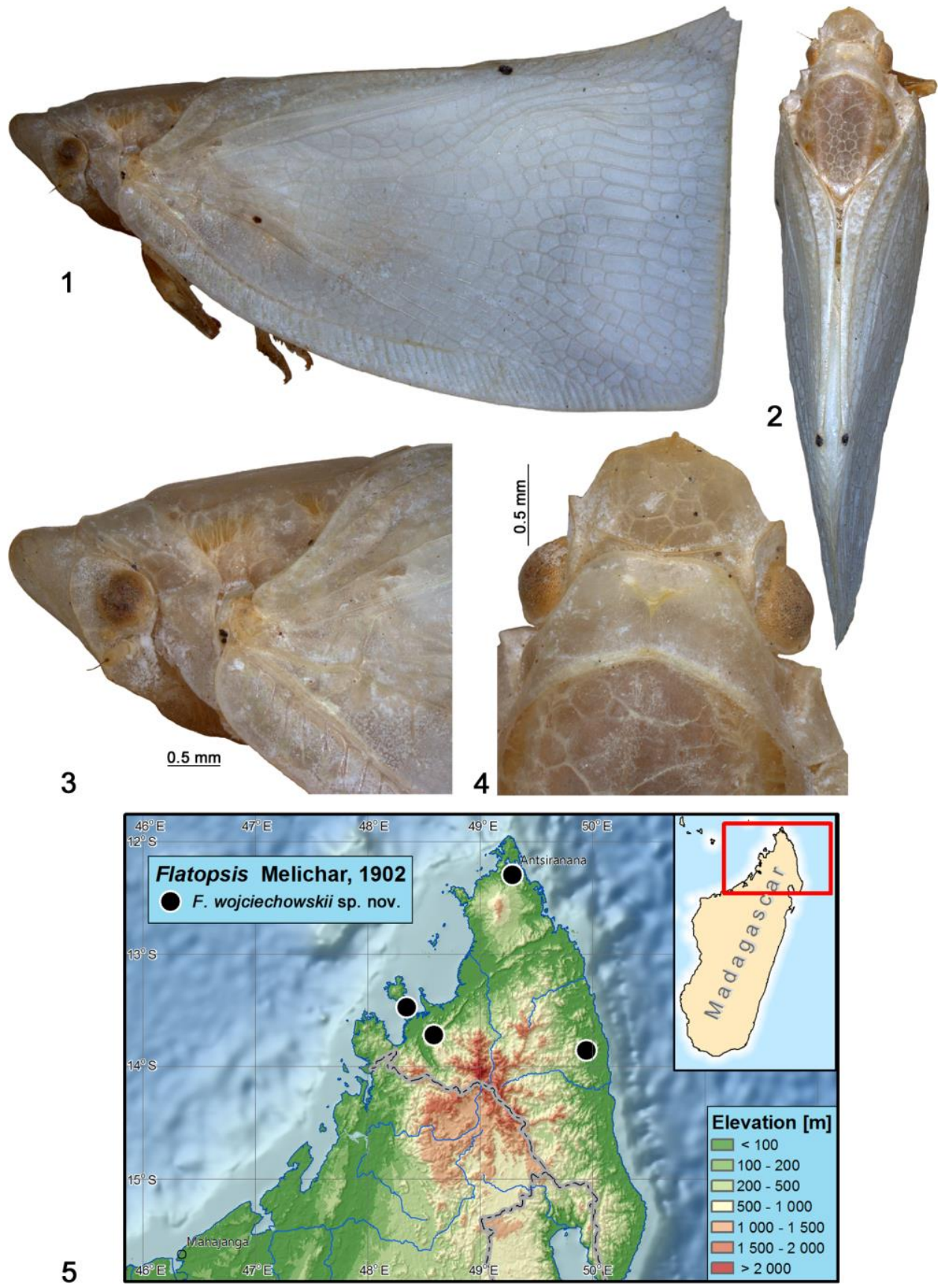

Figs 1-5. Flatopsis wojciechowskii sp. n. 1 - habitus, lateral view; 2 - habitus, dorsal view; $\mathbf{3}$ - anterior part of body, left lateral view; 4 - anterior part of body, dorsal view; 5 - distribution map. 
National Museum Praha, Czech Republic] - $1 \hat{0}$ (NMPC); [Madagascar Sambirano Massif du Manougarivo 450 M. -XII-1960 P. GRIVEAUD], [Museum Paris], [Flatopsis nivea det JTM 1988] - 1ठð (MNHN); [Madagascar Diego-Suarez Ch. Alluaud 1893], [Museum Paris Madagascar Diego-Suarez Ch. ALLUAUd 1893], [Lawanini Flatopsis] - 1 ô $^{\wedge}$ (MNHN).
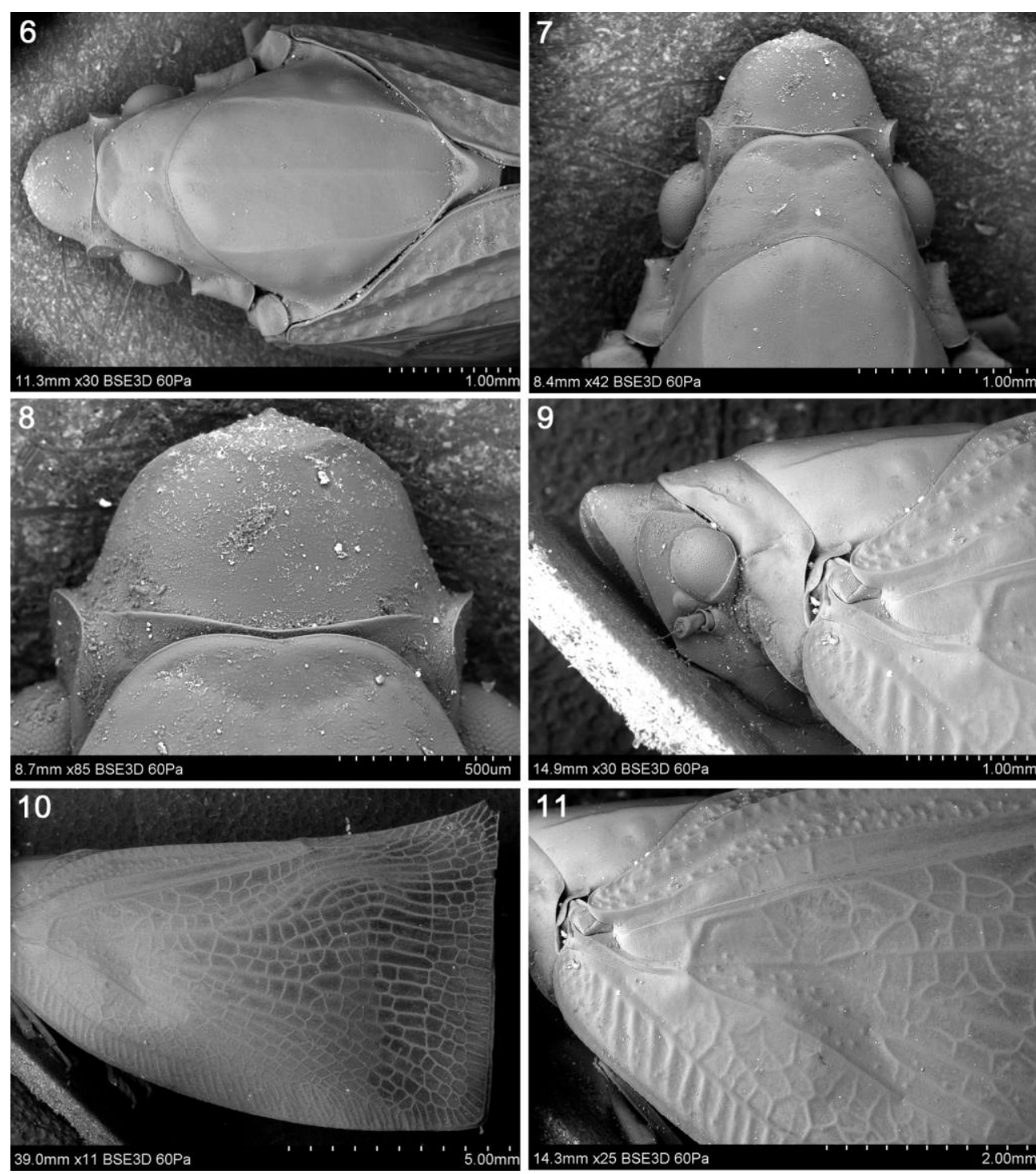

Figs 6-11. Flatopsis wojciechowskii sp. n., SEM images. 6, 7 - anterior part of body, dorsal view; 8 - vertex and pronotum, dorsal view; 9 - anterior part of body, left lateral view; $\mathbf{1 0}$ - left tegmen, general view; $\mathbf{1 1}$ - left tegmen, basal part. 


\section{Description}

Body slender. Total length $11.2-11.6 \mathrm{~mm}$. Head, thorax and abdomen ochraceous. Tegmina milky-white with two black spots placed in basal part and at end of clavus (Figs $1-4)$.

Head conical, with compound eyes (in dorsal view) narrower than thorax (Figs 4, 6). Vertex distinctly wider than long at midline (Figs 4, 7, 8), medially covered by pronotum, proportion $\mathrm{A} / \mathrm{B}=5.91-6.50$; anterior margin elevated and carinate, slightly concave, lateral margins almost straight and parallel, posterior margin deeply arcuate; disc of vertex convex, without carinae. Frons longer than wide, the widest in the line between antennae, proportion $\mathrm{C} / \mathrm{E}=0.67-0.71$, proportion $\mathrm{D} / \mathrm{E}=0.70-0.75$; disc of frons tricarinate - median carina distinctly visible, lateral carinae in shape of elongated horseshoe, connected with median carina at top of head; lateral margins of frons carinated with shallow incision about the level of the compound eye; disc of frons depressed in central part; frons with protrusion in the upper part; margin of frons (in dorsal view) blunt, area between anterior margin of vertex and apex of protrusion smooth. Antennal segment II (pedicel) wider at apex, twice as long as wide, with black flagellum. Compound eyes oval with small callus at lower posterior margin, lateral ocelli present (Fig. 9). Frontoclypeal suture almost straight; clypeus without carinae, median portion convex. Rostrum reaching level of metacoxae; apical part somewhat shorter than basal part.

Pronotum longer at midline than vertex (Figs 4, 7), proportion F/B = 3.18-3.90; anterior margin (in dorsal view) strongly convex and elevated, with shallow incision at midline, posterior margin deeply concave; disc with Y-shaped groove; lateral carinae short, connected with anterior margin; postocular eminences conical. Mesonotum rhomboidal (Figs 2, 6), proportion $\mathrm{G} / \mathrm{F}=3.63-4.14, \mathrm{G} / \mathrm{B}+\mathrm{F}=2.84-3.23, \mathrm{G} / \mathrm{H}=0.94-1.07$; lateral angles situated at about midlength; disc of mesonotum almost flat with three parallel carinae reaching posterior margin. Tegmen elongate-triangular, membranous, flat, surface smooth without any bulla (Figs 10-14), proportion $\mathrm{I} / \mathrm{J}=1.85-2.04$; costal margin - basal part arcuate, apical part almost straight; apical angle almost $90^{\circ}$; apical margin straight; sutural angle acute and slightly produced in relation to apical angle; postclaval sutural margin straight; costal area narrower than postcostal cell at midline, about the same width, with dense and numerous transverse veinlets; postcostal cell in median portion about $1.5 \mathrm{x}$ wider than costal area, tapering apicad, with sparse net of veinlets; basal cell roughly twice as long as wide. Longitudinal stem $\mathrm{ScP}+\mathrm{R}$ arises as extremely short common stem from basal cell, stem MP leaving basal cell with long stalk. Stem ScP+R diverging into ScP+RA and $\mathrm{RP}$ very basad, shortly after leaving basal cell; $\mathrm{ScP}+\mathrm{RA}$ vein branched into $\mathrm{ScP}+\mathrm{RA}_{1}$ and $\mathrm{RA}_{2}$ a little before end of costal area; $\mathrm{RP}$ vein branched into $\mathrm{RP}_{1+2}$ and $\mathrm{RP}_{3+4}$ after MP fork; $\mathrm{RP}_{1+2}$ branched before end of clavus, $\mathrm{RP}_{3+4}$ multiforked; pattern of ultimate apical veins somewhat variable. Stem MP branched in basal part of wing into $\mathrm{MP}_{1+2}$ and $\mathrm{MP}_{3+4}$; 
$\mathrm{MP}_{1+2}$ almost straight, forking a little before $\mathrm{MP}_{3+4}$ fork; $\mathrm{MP}_{3+4}$ from the first fork strongly diverged; mediad branches of $\mathrm{MP}_{4}$ vein ending at postclaval margin and posteroapical angle. $\mathrm{CuA}$ fork distinctly distad of $\mathrm{ScP}+\mathrm{R}$ and MP forks. $\mathrm{CuA}_{1}$ arcuate, delimiting a huge anterocubital cell with a net of veinlets. Tegmina with numerous transverse veinlets forming irregular net; apical line present. Apical cells elongated, 2-3 times longer than wide; tubercles present on basal part of tegmen between ScP+RA, RP and MP veins and on clavus between $\mathrm{PCu}, \mathrm{A}_{1}, \mathrm{~A}_{2}$ veins. Metatibia with 2 lateral, black-topped spines in distal part and arcuate row of apical teeth in formula 2 (longer) +5 (shorter); basitarsomere as long as cumulative length of meta- and hind tarsomeres, with row of small, black-topped teeth, lateral teeth larger than internal ones.

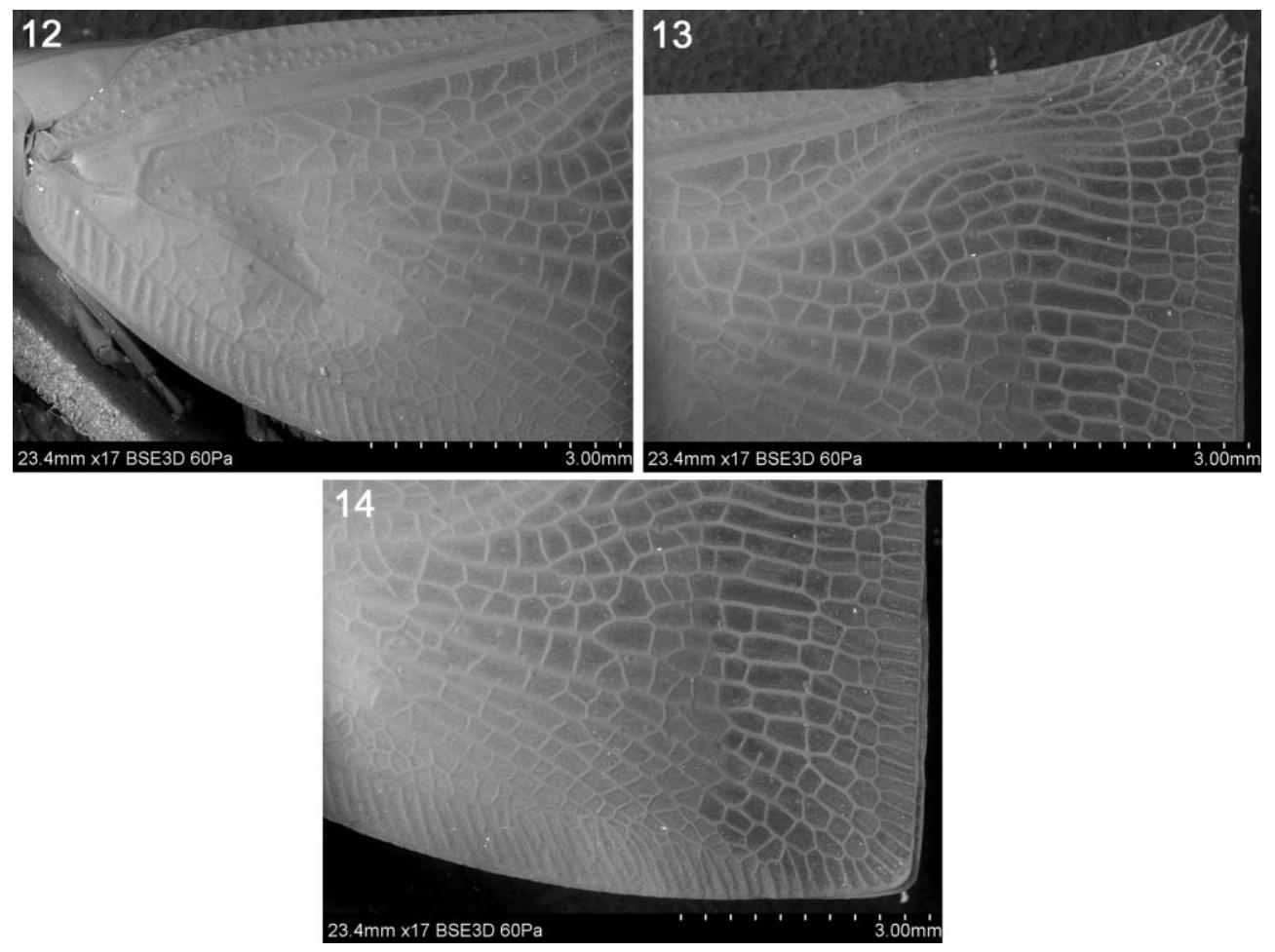

Figs 12-14. Flatopsis wojciechowskii sp. n., tegmen, SEM images. 12 - anterior part; 13 - posterodorsal part; 14 - posteroventral part. 

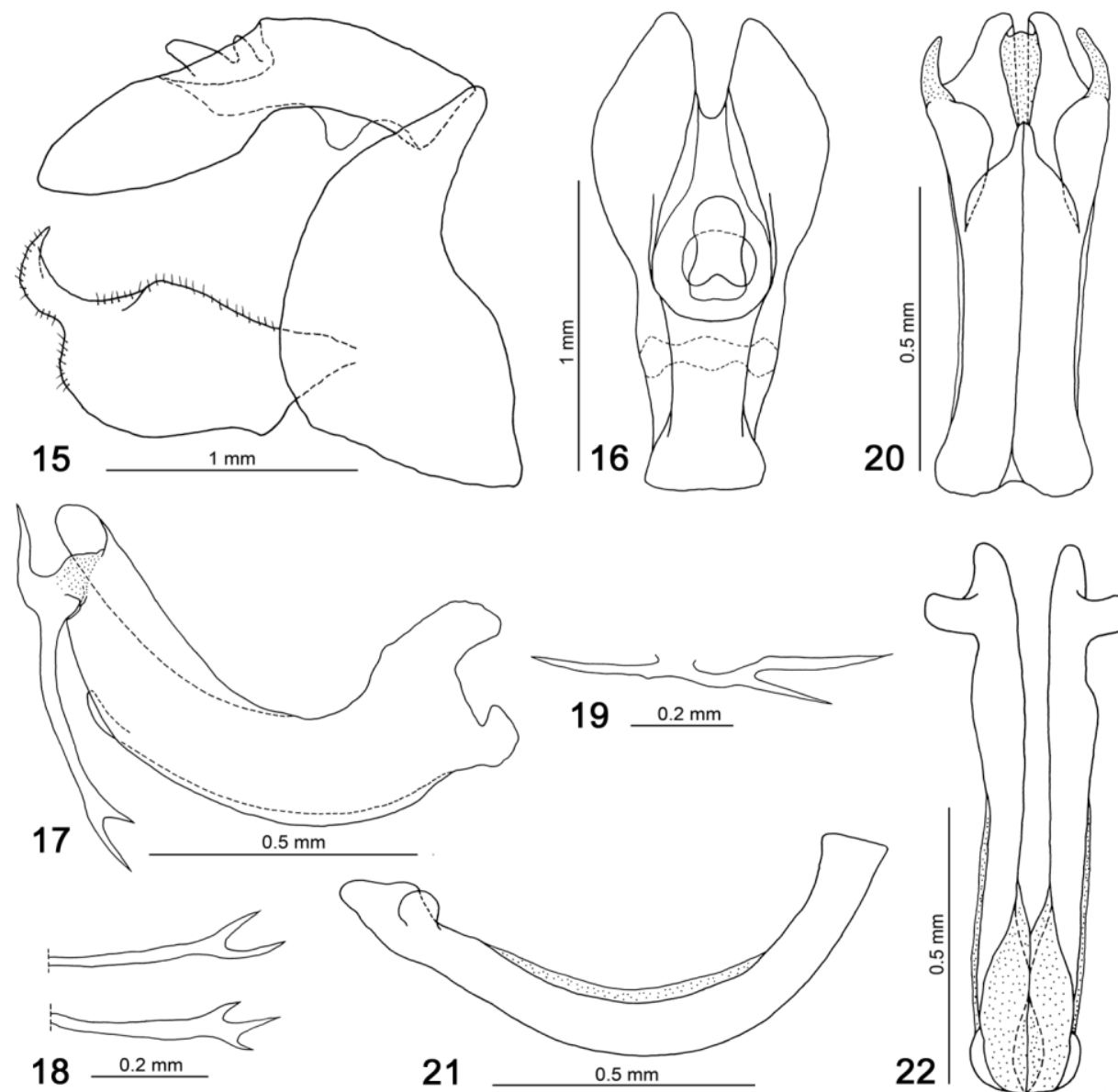

18

\section{1}
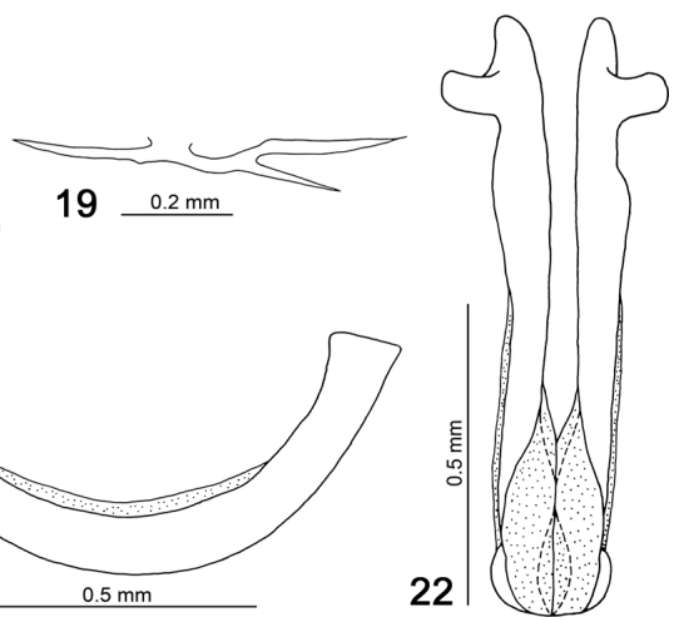

Figs 15-22. Flatopsis wojciechowskii sp. n., male. 15 - genital capsule, lateral view; 16 - anal tube, dorsal view; 17 - periandrium, lateral view; 18 - periandrium processes (paratype from Nosy-Komba); 19 - periandrium process (paratype from Diego-Suarez); 20 - periandrium, ventral view (processes not figured); 21 - aedeagus, lateral view; 22 - aedeagus, ventral view.

Male terminalia. Pygofer (in lateral view, Fig. 15) higher than wide; upper part distinctly narrower than lower, posterior margin convex. Anal tube (in lateral view, Fig. 15) elongated, tapering apicad; dorsal and ventral margins arcuate, ventral side with gibbosity; anus placed slightly after midlength. Anal tube (in dorsal view, Fig. 16) club-like, elongated; anterior margin almost straight, posterior margin deeply incised. Gonostyles (in lateral view, in direct observation, Fig. 15) longer than wide and bearing distinct and sharp capitulum at end of dorsal margin; ventral margin arcuate, dorsal margin with triangular 
eminence. Periandrium (in lateral view, Fig. 17) elongated and curved; lateral split reaching $1 / 3$ of length; dorsal part longer than ventral, with well sclerotized latero-ventral process; process of periandrium with two arms: dorsal arm short and almost straight, oriented apicad-dorsad; ventral arm much longer and curved (shortened in paratype from DiegoSuarez as in Fig. 19), oriented dorso-basad, diverging into 2 projections (3 in paratype from Nosy-Komba as in Fig. 18). Apical part of dorsal periandrium (Fig. 20) divided into two narrow and elongate lobes connected by membrane; ventral periandrium with medially placed, elongated and narrow keel. Aedeagus (Figs 21-22) with shaft as long as dorsal part of periandrium, arcuate, tapered apically; posterior part near apex with lateral, well sclerotized, bulb-like appendage.

\section{Female}

Unknown.

\section{Etymology}

The species was named in honour of Professor Wacław WOJCIECHOWSKI, the eminent Polish hemipterologist.

\section{Distribution}

Northern Madagascar (Antsiranana Province), Nosy-Komba island (Fig. 5).

\section{REFERENCES}

Ali J.R., Aitchison J.C. 2008. Gondwana to Asia: Plate tectonics, paleogeography and the biological connectivity of the Indian sub-continent from the Middle Jurassic through latest Eocene (166-35 Ma). Earth-Science Review 88(3-4): 145-166.

BouRGOIN T. 1988. A new interpretation of the homologies of the Hemiptera male genitalia, illustrated by the Tettigometridae (Hemiptera, Fulgoromorpha). [in:] C. VIDANO, A. ARzonE (eds). $6^{\text {th }}$ Auchenorrhyncha Meeting, Turin, Italy, September 7-11, 1987. CN R-IPRA, Turin, $113-120$.

BouRGOIN T. 1993. Female genitalia in Hemiptera Fulgoromorpha, morphological and phylogenetic data. Annales de la Société entomologique de France (N.s.) 29(3): 225-244.

BouRGOIN T. 2015. FLOW (Fulgoromorpha Lists on The Web): a world knowledge base dedicated to Fulgoromorpha. Version 8, updated [2015-07-02]. Internet: http://hemiptera-databases.org/flow/

Bourgoin T., HuAng J. 1990. Morphologie comparée des genitalia males des Trypetimorphini et remarques phylogénétiques (Hemiptera: Fulgoromorpha: Tropiduchidae). Annales de la Société entomologique de France (N.s.) 26(4): 555-564.

Bourgoin T., Rong-Rong W., Asche M., Hoch H., Soulier-Perkins A., Stroiński A., Yap S., SzWEDO J. 2015. From micropterism to hyperpterism: recognition strategy and standardized 
homology-driven terminology of the forewing venation patterns in planthoppers (Hemiptera: Fulgoromorpha). Zoomorphology 134(1): 63-77.

CARAYON J. 1969. Emploi du noir chlorazol en anatomie microscopique des insectes. Annales de la Société entomologique de France (N.s.) 5(1): 179-193.

GANZHORN J.U., LOWRY II P.P., SchatZ G.E., SOMMER S. 2001. The biodiversity of Madagascar: one the world's hottest hotspots on its way out. Oryx 35(4): 346-348.

Gautier L., Goodman S.M. 2007. Introduction to the Flora of Madagascar. [in:] S.M. Goodman, J.P. BensteAd (eds). The Natural History of Madagascar. The University of Chicago Press, Chicago \& London, 229-250.

McNeely J.A., Miller K.R., Reid W.V., Mittermeier R.A., Werner T.B. 1990. Conserving the World's Biological Diversity. International Union for Conservation of Nature and Natural Resources, World Resources Institute, Conservation International, World Wildlife Fund-US, World Bank, Gland, Switzerland - Washington, D.C.

MelichaR L. 1901. Monographie der Acanaloniiden und Flatiden (Homoptera). Annalen des k.k. Naturhistorischen Hofmuseums 16: 178-258.

Melichar L. 1902. Monographie der Acanaloniiden und Flatiden (Homoptera) (Fortsetzung). Annalen des k.k. Naturhistorischen Hofmuseums 17: 1-253.

Melichar L. 1923. Genera Insectorum fasc. 182. Homoptera, fam. Acanaloniidae, Flatidae et Ricaniidae. Tervuren, Belgium.

Mifsud D., Cocquempot C., Mühlethaler R., Wilson M.W., Streito J.-C. 2010. Chapter 9.4. Other Hemiptera Sternorrhyncha (Aleyrodidae, Phylloxeroidea, and Psylloidea) and Hemiptera Auchenorrhyncha. [in:] A. RoQues, Kenis M., LeEs D., C. Lopez-VAamonde, W. Rabitsch, J.-Y. RASPlus, D.B. RoY (eds.). Alien terrestrial arthropods of Europe. Biorisk 4(1): 511-552.

Myers N., Mittermeier R.A., MitTermeier C.G., DA FonseCa G.A.B., Kent J. 2000. Biodiversity hotspots for conservation priorities. Nature 403: 853-858.

O'BRIEN L. 2002. The Wild Wonderful World of Fulgoromorpha. Denisia (N.F.) 4: 83-102.

SAY T.1830. Descriptions of new North American Hemipterous Insects, belonging to the first family of the section Homoptera of LATREILlE. Journal of the Academy of Natural Sciences of Philadelphia 6: 235-244.

SChмiDT E. 1924. Neue Zikaden-Gattungen und Arten. Entomologische Mitteilungen, Berlin-Dahlem 13: $285-297$.

SignoRet V. 1860. Faune des hémiptères de Madagascar. 1ère partie. Homoptères. Annales de la Société Entomologique de France (Ser. 3) 8: 177-206.

Spinola M. 1839. Essai sur les Fulgorelles, sous-tribu de la tribu des Cicadaires, ordre des Rhyngotes. Annales de la Société Entomologique de France 8: 133-337.

STÅL C. 1866. Hemiptera Homoptera LATR. Hemiptera Africana 4: 1-276.

Stroiński A., GNEZDILOV V., BouRgoin T. 2011. Sub-brachypterous Ricaniidae (Hemiptera: Fulgoromorpha) of Madagascar with morphological notes for these taxa. Zootaxa 3145: 1-70.

ŚWIERCZEWSKI D., STROIŃSKI A. 2011. Flatopsis medleri sp. n. - a new flatid species from Madagascar (Hemiptera: Fulgoromorpha: Flatidae). Acta zoologica cracoviensia 54B(1-2): $23-30$. 
WiLSON S.W., O'Brien L.B. 1986. A Survey of planthopper pests of economically important plants (Homoptera: Fulgoroidea). [in:] M.R. WILSON, L.R. NAULT (eds.). Proceedings of $2^{\text {nd }}$ International Workshop on Leafhoppers and Planthoppers of Economic Importance, Provo, Utah, USA, $28^{\text {th }}$ July- $1^{\text {st }}$ August 1986. CAB International Institute of Entomology, London, 343-360.

Received: 10 July 2015

Accepted: 10 August 2015 